Research article

\title{
Interaction of a fly ash and root-knot nematode pathogens on Pumpkin (Cucurbita moschata Duch. ex Lam.)
}

\section{Gufran Ahmad, Abrar Ahmad Khan and Safiuddin Ansari*}

\author{
Department of Botany, Aligarh Muslim University, Aligarh-202002, Uttar Pradesh, India \\ *Corresponding Author: safiuddin7ansari@gmail.com \\ [Accepted: 26 November 2017]
}

\begin{abstract}
In the present investigation it was tried to find out the interactive effect of various level of fly ash (abiotic) and root-knot nematode, Meloidogyne incognita (biotic) on plant growth, yield and some biochemical contents in pumpkin (Cucurbita moschata). The experiments were conducted in pots with different level of fly ash and soil mixture in the green house at Department of Botany, Aligarh Muslim University, Aligarh, India. Seeds of pumpkin (F1 hybrid-Nutan) were grown in pots filled with different level of fly ash $(5,10,20,30,40$ and 50\%). At four leaves stage, seedlings were inoculated with 2000 larvae (J2 stage) of M. incognita. Plants grown in soil (uninoculated and inoculated stes) serve as control for comparing with different level of fly ashamended soil. Plant growth and yield parameters were increased significantly in 10 to $30 \%$ fly ash amended soils. However, at higher level of fly ash (40\% and 50\%), plant growth and yield were reduced significantly. The suppression in plant growth and yield were maximum at $50 \%$ fly ash level. Similarly the chlorophyll, carotenoids, carbohydrate and proline contents were also increased at 10-30\% levels, then increased in 40 and 50\% of fly ash level compared to control (uninoculated set). All the parameters; growth, yield, chlorophyll, carotenoids, carbohydrate and proline content of plants were better for all the fly ash level as compared to nematode inoculated sets.
\end{abstract}

Keywords: Carotenoids - Carbohydrate - Chlorophyll - Fly ash - Nematodes - Pumpkin.

[Cite as: Ahmad G, Khan AA \& Ansari S (2017) Interaction of a fly ash and root-knot nematode pathogens on Pumpkin (Cucurbita moschata Duch. ex Lam.). Tropical Plant Research 4(3): 449-455]

\section{INTRODUCTION}

Fly ash (FA) is the waste product of coal combustion process for generation of electricity and is accepted as an environmental pollutant. Fly ash contains fine, powder-like particles that are spherical in shape, solid or hollow, and mostly amorphous in nature. Depending on the quantity of unburned carbon in fly ash the color may vary by gray to black. The surface area of FA may vary from 170 to $1000 \mathrm{~m}^{2} \cdot \mathrm{kg}^{-1}$ while the specific gravity ranges by 2.1 to 3.0. Basically four types of coal, each of which varies in terms of its chemical composition, ash content, value of heating and geological origin and are anthracite, bituminous, sub-bituminous, and lignite. Alumina, Silica, Iron oxide and Calcium, with variable amounts of carbon are the components of bituminous fly ash. Higher concentrations of calcium and magnesium oxide and low percentages of iron oxide and silica and carbon contents are characters of lignite and su-bituminous coal fly ashes.

Due to fly ash application, there is an increase in the availability of major nutrients in the soil was reported by Ram et al. (2011). Except K, the increase in the availability major nutrients concluded by Dey et al. (2012). There is an increase in organic carbon by the application of fly ash and farm-yard manure was reported by Karmakar et al. (2009). As an amendment, fly ash is used in agriculture especially due to the presence of macro and micro-nutrients (Wong \& Wong 1986, Raghav \& Khan 2002, Rizvi \& Khan 2009). Fly ash has been found beneficial for the growth of many plants (Mishra \& Shukla 1986, Singh 1989, Pasha et al. 1990, Khan \& Khan 1996, Raghav \& Khan 2002, Rizvi \& Khan 2009).

Root-knot nematodes (Meloidogyne spp.) are microscopic roundworms found in a broad range of habitats and agro-ecosystems. Almost they complete their life cycle in the roots of the host plants; in spite of they can 
survive in the soil as eggs or as second-stage juveniles. The juveniles of first-stage develop within the eggs while juveniles of second-stage hatch from the eggs and infect the roots of the various host plants. Giant cells develop where they obtain nutrients from one permanent site in the root, called sedentary endoparasitism. For the development of root-knot nematodes, the optimum soil temperature should be $25-28{ }^{\circ} \mathrm{C}$. The test plant was pumpkin is commonly applied to any plant in the taxonomically diverse Cucurbita genus and colour of fruit varies yellow to orange. Pumpkin cultivars may belong to one of the several species: Cucurbita pepo L., C. maxima Duch., C. moschata Duch. and C. mixta. Cv. This species, C. moschata has been considered to have many functions for human health as antimicrobial and to preserve kidney function (Caili et al. 2006, El-Aziz \& El-Kalek 2011). Because of the high content of carbohydrates and fibre, this vegetable plant has been performed as a food with an esteemed source of dietary fiber in human nutrition (Hussain et al. 2010) may decrease the serum cholesterol level, the risk of coronary heart disease, and hypertension. Apart from, the seeds of Cucurbita moschata have high amount of zinc, used in treatment of the early stages of prostate problem (Pandya \& Rao 2010). Fly ash has shown its inhibitory effect on root-knot nematodes (Tarannum et al. 2001, Raghav \& Khan 2002, Rizvi 2008, Rizvi \& Khan 2009) however their combined effects on cucurbits so far.

\section{MATERIAL AND METHODS}

The experiments were conducted in glass houses at the Department of Botany, Aligarh Muslim University, Aligarh. The fresh fly ash was collected from Thermal Power Plant, Kasimpur for the experiment. The test pathogen, Meloidogyne incognita Chitwood was maintained in pure form. Pumpkin (Cucurbita moschata) var. NUTAN (F1 hybrid) was selected as a test plant for the experiments. Inoculums were prepared by incubating the egg masses of pure $M$. incognita in distilled water. The freshly hatched second stage (J2) juveniles were collected as water suspension and the number of $\mathrm{J} 2$ counted in ten $1 \mathrm{ml}$ samples from the suspension. The average numbers of $\mathrm{J} 2$ were used to represent the number of second juveniles (J2) per $\mathrm{ml}$ of suspension. The soil used in the experiment was collected from the unpolluted agricultural field up to $20 \mathrm{~cm}$ depth after scrapping the surface of litters present. The collected soil was brought to the laboratory in gunny bags.

For this experiment, fly ash was mixed with autoclaved soil in different proportion to prepare 10, 20, 30, 40 and 50\% levels. The clay pots of 12 inches height $(20 \mathrm{~cm}$ diam.) were filled with $2 \mathrm{~kg}$ of each type of mixture. Ten days old plants were inoculated with 2,000 juveniles. The treatments were given as below,

$$
\begin{aligned}
& \mathrm{T} 1=\text { Control } \\
& \mathrm{T} 2=\text { Nematode }(2000 \mathrm{~J} 2 \text { of Meloidogyne incognita }) \\
& \mathrm{T} 3=10 \% \text { Fly ash }+\mathrm{N} \\
& \mathrm{T} 4=20 \% \text { Fly ash }+\mathrm{N} \\
& \mathrm{T} 5=30 \% \text { Fly ash }+\mathrm{N} \\
& \mathrm{T} 6=40 \% \text { Fly ash }+\mathrm{N} \\
& \mathrm{T} 7=50 \% \text { Fly ash }+\mathrm{N}
\end{aligned}
$$

\section{Fly ash effect on development of the nematode juvenile}

Fly ash and autoclaved soil were mixed as above proportion. Pots containing only autoclaved soil served as controls. A total of 140 pots ( 7 treatments $\times 4$ weekly observations $\times 5$ replicates) were prepared. A 15 -day-old seedling of pumpkin at the four leaves stage was kept on a glasshouse bench at $25-27^{\circ} \mathrm{C}$ and each seedling was inoculated with 2000 juveniles of $M$. incognita. Five seedlings were harvested from each treatment at different intervals $\left(1^{\text {st }}, 2^{\text {nd }}, 3^{\text {rd }}\right.$ and $4^{\text {th }}$ week) and roots were cut and gently wash under tap water. After cutting, the roots were taken into test tube with distilled water and boil under spirit lamp for 2 minutes. After boiling 2-3 drops of acid fuschin add in each tube for staining and then roots were kept on slide. After this, different developmental stages of the nematode were counted under a stereoscopic microscope.

\section{Plant growth and yield}

The plant growth (length, fresh weight and dry weight of root and shoot/plant) and yield (flower/plant; fruit/plant) were taken after termination of experiments. Shoot length was taken from the point of emergence of the root to the shoot apex. While root length was recorded from root emergence to longest root and both were recorded in centimeter $(\mathrm{cm})$. Fresh weight of roots and shoots were recorded in gram $(\mathrm{g})$. After taking fresh weight, roots and shoots were dried in a hot air oven at $80^{\circ} \mathrm{C}$ for $48 \mathrm{hrs}$ and their dry weights were recorded.

\section{Photosynthetic pigments}

Photosynthetic pigments were estimated by Maclachlan \& Zalik (1963) method. After 120 days of planting, www.tropicalplantresearch.com 
one $\mathrm{g}$ fresh leave was ground in $80 \%$ acetone with the help of mortar and pestle. The suspension was filtered through the Whatman filter paper No. 1 to the $100 \mathrm{ml}$ volumetric flask and made to the known volume by adding 80\% acetone. Optical density (O.D.) was read at $645 \mathrm{~nm}$ and $663 \mathrm{~nm}$ for chlorophyll a and b and at 480 $\mathrm{nm}$ and $510 \mathrm{~nm}$ for carotenoids against $80 \%$ acetone as blank on spectrophotometer. The concentration of chlorophyll $\mathrm{a}$, chlorophyll $\mathrm{b}$ and total chlorophyll $(\mathrm{a}+\mathrm{b})$ and carotenoids present in the given extract were calculated according to the formulae given below,

i) $\quad \mathrm{Chl} \mathrm{a}=12.7($ O.D. 663) -2.69 (O.D.645) $\times \mathrm{V} / 1000 \times \mathrm{W}(\mathrm{mg} / \mathrm{g})$

ii) $\mathrm{Chl} \mathrm{b}=22.9$ (O.D. 645) $-4.68($ O.D.663 $) \times \mathrm{V} / 1000 \times \mathrm{W}(\mathrm{mg} / \mathrm{g})$

iii) Total Chl $(\mathrm{a}+\mathrm{b})=20.2($ O.D.645) $-8.02($ O.D.663 $) \times \mathrm{V} / 1000 \times \mathrm{W}(\mathrm{mg} / \mathrm{g})$

iv) Carotenoids $=7.6($ O.D.480 $)-1.49($ O.D.510) $/ \mathrm{D} \times 1000 \times \mathrm{W}(\mathrm{mg} / \mathrm{g})$

\section{Carbohydrate content}

Carbohydrates are dehydrated with concentrated $\mathrm{H}_{2} \mathrm{SO}_{4}$ to form "Furfural", which condenses with anthrone to form a green color complex which can be measured by using colorimetrically at $620 \mathrm{~nm}$ (or) by using a red filter. Anthrone reacts with dextrins, monosaccharides, disaccharides, polysaccharides, starch, gums and glycosides. But they yields of color where is to form carbohydrate. Anthrone reagent: Dissolve $200 \mathrm{mg}$ of anthrone reagent in $100 \mathrm{ml}$ of concentrated $\mathrm{H}_{2} \mathrm{SO}_{4}$.

To take 0.2 to $1 \mathrm{ml}$ of working standard solution of five different test tube and add water to bring the volume to $1 \mathrm{ml}$ in each test tube add $4 \mathrm{ml}$ of anthrone reagent and mix the contents as well and cover the test tube with bath for $10 \mathrm{~min}$ then cool the test tube to the room temperature and measure the optical density in a photoelectric colorimeter at $620 \mathrm{~nm}$ (or) by using a red filter. Simultaneously prepare a blank with $1 \mathrm{ml}$ of distilled water and $4 \mathrm{ml}$ of anthrone reagent. Construct a calibration curve on a graph paper, by plotting the glucose concentration (10 to $100 \mathrm{mg}$ ) on $\mathrm{x}$-axis and absorbance at $620 \mathrm{~nm}$ on the y-axis. Compute the concentration of the sugar in the sample from the calibration curve. While calculating the sugar concentration in the unknown sample, the dilution factor has to be taken into account. For the calculation of total carbohydrate content following formula are required-

Amount of carbohydrate present in $100 \mathrm{mg}$ of the sample $=\mathrm{mg}$ of glucose/Volume sample $\times 100$

\section{Proline estimation}

Proline is very soluble and can be readily extracted by heating explants or aliquots of ground plant material for $20 \mathrm{~min}$ in pure ethanol as well as in water. Proline can also be extracted together with total amino acids, pigments, soluble sugars by heating plant material twice with $80 \%$ ethanol and once with $50 \%$ ethanol as described by Cross et al. (2006), which results into a 70:30 ethanol: water mixture (v/v). Proline and total amino acids may also be extracted using a cold extraction procedure by mixing $20-50 \mathrm{mg}$ fresh weight aliquots with $0.4-1.0 \mathrm{ml}$ of ethanol : water $(40: 60 \mathrm{v} / \mathrm{v})$. The resulting mixture is left overnight a $4{ }^{\circ} \mathrm{C}$, and then centrifuged at $14000 \mathrm{~g}(5 \mathrm{~min})$. The cold extraction procedure can be repeated on the pellet and supernatants pooled and used for the analyses. The first extraction, however, already allows a recovery > 93\% (Carillo et al. 2008).

\section{Calculation}

$\mu$ moles per $\mathrm{g}$ tissue $=\mu \mathrm{g}$ proline $/ \mathrm{ml} \mathrm{x} \mathrm{ml} \mathrm{toluene} / 115.5 \times 5 / \mathrm{g}$ sample

Where, 115.5 is the molecular weight of proline

\section{RESULTS}

The development of juveniles of meloidogyne incognita in the roots of pumpkin shows in table 1 was also significantly suppressed by all fly ash and soil mixtures. The J2 developed to J3 /J4 stages at all levels of fly ash amendment, but their number were less than in the control and decreased with the increase of the fly ash up to $40 \%$ soil mixture. At the end of the first week, neither premature nor mature females were found. During the second week, J2 developed to older stages. However, while pre-mature females occurred in all roots only a few mature females occurred in the control and at the 5-10\% levels of fly ash and none at larger proportions of the amendment. During the third week, the juveniles that had penetrated into the roots developed further. However, numbers of pre-mature females were significantly suppressed by all proportions of fly ash while mature females were significantly suppressed at $5-10 \%$ of this amendment and were still absent at larger proportions. After 4 weeks, all the $\mathrm{J} 3 / \mathrm{J} 4$ had developed further but pre-mature females were still significantly less than in the control 
at all proportions of the amendment and a few mature females were observed only up to $20 \%$ of the amendment, with none at all at greater proportions.

Table 1. Effect of different levels of fly ash on developmental stages of Meloidogyne incognita in roots of pumpkin (Cucurbita moschata), after 1, 2,3, and 4 weeks from inoculation of nematode juveniles.

\begin{tabular}{|c|c|c|c|c|c|c|c|c|c|c|c|c|c|c|c|c|}
\hline \multirow{2}{*}{$\begin{array}{l}\text { Fly ash } \\
\text { level } \\
(\%)\end{array}$} & \multicolumn{4}{|c|}{$\begin{array}{l}\text { Developmental stages } \\
\text { One week }\end{array}$} & \multicolumn{4}{|c|}{$\begin{array}{c}\text { Developmental stages } \\
\text { Tow week }\end{array}$} & \multicolumn{4}{|c|}{$\begin{array}{c}\text { Developmental stages } \\
\text { Three week }\end{array}$} & \multicolumn{4}{|c|}{$\begin{array}{c}\text { Developmental stages } \\
\text { Four week } \\
\end{array}$} \\
\hline & $\mathbf{J 2}$ & J3/J4 & $\mathbf{P}$ & $\mathbf{M}$ & $\mathbf{J} 2$ & J3/J4 & $\mathbf{P} \bigcirc$ & $\mathbf{M}$ ㅇ & $\mathbf{J} 2$ & J3/J4 & $\mathbf{P}_{+}$ & $\mathbf{M}$ ㅇ & $\mathbf{J} 2$ & J3/J4 & $\mathbf{P} \bigcirc$ & $\mathbf{M}_{+}$ \\
\hline Control & 155 & 405 & - & - & 138 & 156 & 118 & 32 & - & 168 & 201 & 71 & - & - & 98 & 140 \\
\hline 5 & 166 & 378 & - & - & 132 & 138 & 98 & 11 & - & 148 & 175 & 24 & - & - & 82 & 46 \\
\hline 10 & 201 & 310 & - & - & 164 & 110 & 75 & - & - & 142 & 171 & 16 & - & - & 40 & 15 \\
\hline 20 & 229 & 260 & - & - & 175 & 98 & 53 & - & - & 132 & 161 & 10 & - & 13 & 30 & - \\
\hline 30 & 274 & 190 & - & - & 188 & 79 & 36 & - & - & 105 & 137 & - & 16 & 69 & 21 & - \\
\hline 40 & 235 & 105 & - & - & 134 & 95 & 17 & - & 108 & 160 & 89 & - & 21 & 102 & 14 & - \\
\hline 50 & 187 & 75 & - & - & 96 & 73 & - & - & 88 & 139 & 28 & - & 27 & 130 & 09 & - \\
\hline LSD at $5 \%$ & 14.2 & 23.7 & & & 2.1 & 5.3 & & & & 7.0 & 9.1 & & & & 8.1 & \\
\hline
\end{tabular}

The data given in table 2 shows that the growth (length of shoot and root, fresh and dry weight of shoot and root) and yield (flowers/plant and fruits/plant) parameters of pumpkin were increased significantly in 5, 10, 20 and 30\% levels of fly ash and $M$. incognita combinations compared to uninoculated (only soil) control set. The maximum increment in all above parameters was observed at $30 \%$ level of fly ash and M. incognita combination. But plant growth and yield parameters in higher levels $(40 \%+M$. incognita and $50 \%+M$. incognita combinations) were reduced significantly $(\mathrm{P}=0.05)$ compared to control set and maximum being at $50 \%$ FA and Mi level.

Table 2. Effect of different doses of fly ash and root-knot nematodes (Meloidogyne incognita) on growth and yield parameters of pumpkin (Cucurbita moschata).

\begin{tabular}{lllllllll}
\hline \multirow{2}{*}{$\begin{array}{l}\text { Concentration } \\
\text { of fly ash }\end{array}$} & \multicolumn{2}{c}{ Length (cm) } & \multicolumn{2}{c}{ Fresh weight (gm) } & \multicolumn{2}{c}{ Dry weight (gm) } & \multicolumn{2}{c}{ Number/Plant } \\
\cline { 2 - 8 } & Root & Shoot & Root & Shoot & Root & Shoot & Flower & Fruits \\
\hline C (Soil) & $60 \pm 2.96$ & $281 \pm 12.91$ & $62.4 \pm 2.79$ & $223.4 \pm 10.67$ & $9.1 \pm 0.46$ & $32.2 \pm 1.45$ & $25 \pm 1.23$ & $24 \pm 0.95$ \\
C (Nematode) & $42 \pm 2.00$ & $216 \pm 11.99$ & $54.6 \pm 2.95$ & $201.1 \pm 9.61$ & $6.3 \pm 0.26$ & $25.0 \pm 1.21$ & $23 \pm 1.47$ & $20 \pm 0.87$ \\
$5 \%$ FA + N & $52 \pm 2.25$ & $232 \pm 9.75$ & $59.6 \pm 2.11$ & $214.4 \pm 9.87$ & $7.1 \pm 0.20$ & $29.2 \pm 1.54$ & $21 \pm 0.88$ & $20 \pm 0.87$ \\
$10 \%$ FA + N & $54 \pm 2.18$ & $253 \pm 11.05$ & $63.4 \pm 2.94$ & $220.2 \pm 1.45$ & $8.3 \pm 0.44$ & $33.1 \pm 1.55$ & $22 \pm 1.21$ & $21 \pm 1.06$ \\
$20 \%$ FA + N & $57 \pm 3.00$ & $265 \pm 11.68$ & $68.2 \pm 1.93$ & $231.1 \pm 10.15$ & $10.2 \pm 0.36$ & $35.2 \pm 1.30$ & $24 \pm 1.39$ & $22 \pm 1.18$ \\
$30 \%$ FA + N & $61 \pm 3.29$ & $282 \pm 12.12$ & $71.0 \pm 2.00$ & $250.0 \pm 6.93$ & $13.5 \pm 0.6 C$ & $38.0 \pm 1.71$ & $26 \pm 1.05$ & $25 \pm 0.87$ \\
$40 \%$ FA + N & $50 \pm 3.00$ & $224 \pm 8.85$ & $54.6 \pm 2.33$ & $220.4 \pm 10.13$ & $7.2 \pm 0.30$ & $29.3 \pm 1.47$ & $21 \pm 1.00$ & $17 \pm 0.85$ \\
$50 \%$ FA + N & $45 \pm 2.65$ & $202 \pm 11.38$ & $47.6 \pm 2.05$ & $198.2 \pm 9.91$ & $5.5 \pm 0.27$ & $23.2 \pm 1.13$ & $18 \pm 0.87$ & $14 \pm 0.87$ \\
LSD-P $\leq 0.05$ & 6.5 & 20.8 & 4.4 & 19.2 & 1.32 & 2.1 & 2.3 & 2.0 \\
\hline
\end{tabular}

Note: C, Control; Each value is a mean of five replicates, \pm values shows the standard deviation with mean.

Table 3. Effect of different doses of fly ash and root-knot nematode (Meloidogyne incognita) on some biochemical parameters of pumpkin (Cucurbita moschata).

\begin{tabular}{|c|c|c|c|c|c|c|}
\hline \multirow{2}{*}{$\begin{array}{l}\text { Concentration } \\
(\%) \text { of Fly ash }\end{array}$} & \multicolumn{3}{|c|}{ Chlorophyll (mg.g ${ }^{-1}$ fresh leaf) } & \multirow{2}{*}{$\begin{array}{c}\text { Carotenoids } \\
\left(\mathrm{mg} . \mathrm{g}^{-1} \text { fresh leaf }\right)\end{array}$} & \multirow{2}{*}{$\begin{array}{c}\text { Carbohydrate } \\
\text { ( } \mu \mathrm{g} \text { fresh weight) }\end{array}$} & \multirow{2}{*}{$\begin{array}{c}\text { Proline } \\
\left(\mu \mathrm{mol} . \mathrm{g}^{-1} \text { fresh weight }\right)\end{array}$} \\
\hline & $\mathbf{a}$ & b & Total & & & \\
\hline Control & $0.82 \pm 0.091$ & $0.49 \pm 0.015$ & $1.31 \pm 0.038$ & $0.46 \pm 0.105$ & $14.17 \pm 1.054$ & $23.3 \pm 1.952$ \\
\hline Nematodes & $0.68 \pm 0.079$ & $0.39 \pm 0.007$ & $1.07 \pm 0.069$ & $0.35 \pm 0.098$ & $10.02 \pm 1.127$ & $18.58 \pm 2.100$ \\
\hline $5 \%+\mathrm{N}$ & $0.81 \pm 0.088$ & $0.46 \pm 0.009$ & $1.27 \pm 0.096$ & $0.44 \pm 0.130$ & $11.23 \pm 0.954$ & $19.02 \pm 2.032$ \\
\hline $10 \%+\mathrm{N}$ & $0.91 \pm 0.124$ & $0.47 \pm 0.012$ & $1.39 \pm 0.059$ & $0.45 \pm 0.121$ & $11.98 \pm 0.915$ & $19.99 \pm 1.638$ \\
\hline $20 \%+\mathrm{N}$ & $0.95 \pm 0.048$ & $0.52 \pm 0.010$ & $1.47 \pm 0.046$ & $0.46 \pm 0.136$ & $12.05 \pm 1.014$ & $21.22 \pm 1.947$ \\
\hline $30 \%+\mathrm{N}$ & $0.98 \pm 0.022$ & $0.55 \pm 0.006$ & $1.53 \pm 0.082$ & $0.47 \pm 0.156$ & $15.05 \pm 1.583$ & $24.77 \pm 2.947$ \\
\hline $40 \%+\mathrm{N}$ & $0.81 \pm 0.188$ & $0.48 \pm 0.007$ & $1.30 \pm 0.103$ & $0.43 \pm 0.182$ & $11.99 \pm 1.890$ & $22.32 \pm 2.629$ \\
\hline $50 \%+\mathrm{N}$ & $0.79 \pm 0.037$ & $0.46 \pm 0.011$ & $1.28 \pm 0.008$ & $0.42 \pm 0.103$ & $10.95 \pm 0.961$ & $20.87 \pm 2.722$ \\
\hline LSD-P $\leq 0.05$ & 0.016 & 0.008 & 0.009 & 0.007 & 0.83 & 1.34 \\
\hline
\end{tabular}

Note: Each value is a mean of five replicates, \pm values shows the standard deviation with mean.

Similar pattern of increase/decrease in photosynthetic pigments (chl. a, chl. b, chl. a+b and carotenoids), carbohydrate and proline content of pumpkin were also observed in all fly ash $+M$. incognita treatments when compared to control one shows in table 3. However, maximum increment was found at $30 \%$ fly ash $+M$. incognita. When growth, yield and photosynthetic pigments, carbohydrate and proline content of pumpkin in different fly ash and $M$. incognita combinations were compared to inoculated set (nematode alone), it was 
observed that all parameters were increased significantly $(\mathrm{P}=0.05)$. And all above biochemical parameters decreased significantly at 40\% FA + Mi and 50\% FA + Mi combinations and maximum at 50\% level of FA and nematode.

\section{DISCUSSION AND CONCLUSION}

Several beneficial nutrients including $\mathrm{S}, \mathrm{B}, \mathrm{Ca}, \mathrm{Mg}, \mathrm{Fe}, \mathrm{Cu}, \mathrm{Zn}, \mathrm{Mn}$, and $\mathrm{P}$, which are responsible for plant growth, found in fly ash. It is known that plants take up nitrogen in the form of nitrate (NO3-) because nitrates are more quickly available to plants as they move through the roots and as such lesser content of nitrate in 5\% and $10 \%$ fly ash containing fields may be due to more hydraulic absorption because of higher water holding capacity in the fly ash amended soi. Fly ash decreases porosity and thus increases water holding capacity. This would facilitate the absorption of nutrients as well as photosynthetic activity. Similar findings have been reported by (Thetwar 2007). In the present study, soil amendment with fly ash was harmful to the nematode at all levels. The alkaline nature of fly ash may have directly affected the juveniles, leading to less penetration into the roots and subsequently delayed development. Edongali (1982) stated that juvenile penetration is affected by the concentration of different elements, irrespective of the type of element in the soil solution. We found higher chlorophyll a and b concentration in cucurbita moschata plant could be due to the micronutrients available in fly ash than the control. Similar reports have been made by (Niyaz \& Singh 2006, Hisamuddin \& Singh 2007). Pumpkin plant grows in soil with different doses of fly ash and did not show any visible injury and the lower at $30 \%$ level of fly ash was found beneficial to plant growth, yield, photosynthetic pigments, carbohydrate and proline contents of pumpkin.

The soil application of fly ash ameliorated plant growth of pumpkin and suppressed the M. incognita in pots. Improved plant growth with fly ash has been observed earlier (Elseewi et al. 1980, Mishra \& Shukla 1986). Due to the better health status of the plant, the yield, photosynthetic pigments, carbohydrate, proline contents of pumpkin were also increased. The beneficial effects of fly ash were found from 10 to $30 \%$ levels in soil, and optimum being at $30 \%$. Similar beneficial effects on above parameters have also been observed on a number of crops like cabbage, Capsicum, chickpea, collard greens, com, cucumber, Lactuca sativa, mustard green, radish, soybean, sunflower, tomato, Vigna mungo, wheat etc. (Singh 1989, Menon et al. 1990, Khan \& Khan 1996, Rengifo et al. 1996, Sarangi \& Mishra 1998, Sahu \& Dwivedi 1999, Tarannum et al. 2001, Upadhyay \& Khan 2002, Upadhyay 2004). However, the responses of various crops were different to different levels of fly ash (10-50\%). Higher level adversely affected the plant growth and other parameters of Pumpkin. The adverse effects of fly ash at higher level of application are attributed to excess of micro-nutrients (Adriano et al. 1980) and toxicity of compounds like dibenzofuron and dibenzo-p-dioxine as well as heavy metals found in fly ash (Helder et al. 1982, Mishra \& Shukla 1986, Wong \& Wong 1986). Harmful effects of higher levels above 50\% have been observed on Brassica juncea, chickpea, cucumber, lentil, Linum usitatissimum, maize, potato, soybean and tomato (Mishra \& Shukla 1986, Pasha et al. 1990, Raghav 2006). On the other hand, the soil application of fly ash noticed the effect of $M$. incognitai with respect to levels. This might be due to the excess of salts, toxic compounds and heavy metals which caused nematicidal effects on $M$. incognita either directly or within the host. Nematode might have lost its activities and later could not survive under the stress of fly ash. Losing the activity and not reaching the mature stage of $M$. incognita is very important for the agriculture point of view, because there will be no loss to the crop (Khan 2007, Iram 2010). Thus soil application of fly ash with $30 \%$ level is useful, as it suppresses the, M. incognita one hand, and improves the Pumpkin crop on the other hand.

\section{ACKNOWLEDGEMENTS}

The authors wish to thank the Charirman, Department of Botany, Aligarh Muslim University, Aligarh for providing the infrastructure facilities and support.

\section{REFERENCES}

Adriano DC, Page AL, Elseewi AA, Chang AC \& Straughan IA (1980) Utilization and disposal of fly ash and other coal residues in terrestrial ecosystems: A review. Journal of Environmental Quality 9: 333-344.

Caili FU, Shi Huan \& Quanhong LI (2006) A review on pharmacological activities and utilization technologies of pumpkin. Plant Foods for Human Nutrition 61: 73-80.

Carillo P, Mastrolonardo G, Nacca F, Parisi D, Verlotta A \& Fuggi A (2008) Nitrogen metabolism in durum 
wheat under salinity: accumulation of proline and glycine betaine. Functional Plant Biology 35: 412-426.

Cross JM, von Korff M, Altmann T, Bartzetko L, Sulpice R, Gibon Y, Palacios N \& Stitt M (2006) Variation of Enzyme Activities and Metabolite Levels in 24 Arabidopsis Accessions Growing in Carbon-Limited Conditions. Plant Physiology 142: 1574-1588.

Dey BS, Panigrahi S, Panigrahi T \& Panda RB (2012) Agricultural utilization of fly ash - a way for sustainable agriculture practice and its environmental significance. Discovery Nature 1: 11-14.

Edongali (1982) Varietal Response of Tomato to the Interaction of Salinity and Meloidogyne incognita Infection. Journal of Nematology 14(1): 57-62.

El-Aziz ABA \& El-Kalek HHA (2011) Antimicrobial Proteins and Oil Seeds from Pumpkin (Cucurbita moschata). Nature and Science 9(3): 105-119.

Elseewi AA, Straughan IR \& Page AL (1980) Sequential cropping of fly ash-amended soils: Effects on soil chemical properties and vield and elemental composition of plants. Science of the Total Environment 15: 247-259.

Helder T, Stulterheim E \& Olie K (1982) The toxicity and toxic potential of fly ash from municipal incinerators assessed by means of a flsh carK' life stage test. Chemosphere 11: 965-972.

Hisamuddin \& Singh S (2007) Influence of root-knot nematode disease on yield and biomass production of Pisum sativum in fly ash amended soil. In: XXX All India Botanical Conference, November, 2007, pp. $28-30$.

Hussain J, Rehman N, Khan AL, Hamayun M, Hussain SM \& Shinwari ZK (2010) "Proximate and Nutrients Evaluation of Selected Vegetables Species from Kohat Region Pakistan” Pakistan. Pakistan Journal of Botany 42: 2847-2855.

Iram (2010) Utilization of fly ash for the management of root-knot nematodes on some vegetable crops, Ph.D. Thesis. Aligarh Muslim University, Aligarh.

Karmakar S, Mittra BN \& Ghosh BC (2009) Influence of Industrial Solid Wastes on Soil-Plant Interaction in Rice Under Acid Lateritic Soil. World of Coal Ash (WOCA) Conference held May 4-7, 2009 in Lexington, KY, USA.

Khan AA (2007) Management of root-knot nematodes by application of fly ash (Final technical report). DST, New Delhi (No SR/So/AS-49/2002).

Khan MR \& Khan MW (1996) Effect of fly ash on plant growth and yield of tomato. Environmental Pollution 92: $105-111$.

Maclachlan C \& Zalik S (1963) Plastid structure, chlorophyll concentration and free amino acid composition of a chlorophyll mutant of barley. Canadian Journal of Botany 41: 1053-1062.

Menon MP, Ghuman GS, James J \& Chandra K (1990) Physicochemical characterization of water extracts of different coal fly ashes and fly ash amended composts. Water, Air, \& Soil Pollution 50: 343-353.

Mishra LC \& Shukla KN (1986) Effect of fly ash deposition on growth, metabolism and dry matter production of maize and soxbean. Environmental Pollution 42: 1-13.

Niyaz T \& Singh S (2006) Effect of fly ash amended soil on the plant growth, yield, chlorophyll and oil content of Mentha citrata. National Symposium on Issue and Challenges for Environmental management,Vision. 2025. 55-56.

Pandya JB \& Rao TVR (2010) Analysis of certain biochemical changes associated with growth and ripening of Cucurbita moschata Duch. fruit in relation to its seed development. PRAJNA - Journal of Pure and Applied Sciences 18: 34-39.

Pasha MJ, Khan MW \& Siddiqui ZA (1990) Effect of soil amendment with fly ash of thermal power plant origin on root-knot nematode on cucumber. Nematologica 36: 381.

Raghav D (2006) Studies on the effects of particulate air pollutants application on potato (Solamim tuberosum L.), Ph.D. Thesis. Aligarh Muslim University, Aligarh. India.

Raghav D \& Khan AA (2002) Impact of industrial paniculate pollutants applied to soil on growth and yield of tomato. Thai Journal of Agricultural Science 35: 187-194.

Ram LC, Masto RE, Singh S, Tripathi RC, Jha SK, Srivastava NK, Sinha AK, Selvi VA \& Sinha A (2011) An Appraisal of Coal Fly Ash Soil Amendment Technology (FASAT) of Central Institute of Mining and Fuel Research (CIMFR). World Academy of Science, Engineering and Technology 52: 703-714.

Rengifo JC, Ramirez G \& Bruzon CSF (1996) Importance of filter press cake as a substrate for vegetable seedling production. Acta Agronómica 46: 37-43. 
Rizvi R \& Khan AA (2009) Effect of fly ash and brick kiln dust-extracts on hatching and mortality of root-knot nematodes, Meloidogyne javanica. Katsina Journal of Natural and Applied Sciences 1: 7-14.

Rizvi R (2008) Evaluation of industrial particulate wastes against root-knot nematodes, Meloidogune javanica on eggplant (Solanum melogena L.), M.Phil. Dissertation. Aligarh Muslim University, Aligarh, India.

Sahu V \& Dwivedi SK (1999) Effect of tly ash on seed germination, plant growth and chlorophyll content of two crops of economic importance. Acta Botanica Indica 27: 145-149.

Sarangi PK \& Mishra PC (1998) Soil metabolic activities and yield in groundnut, ladies finger and radish in tly ash amended soil. Research Journal of Chemistry and Environment 2: 7-13.

Singh SK (1989) Studies on interaction of air pollutants and root-knot nematodes on some pulse crops, Ph.D. Thesis. Aligarh Muslim University. Aligarh, India.

Tarannum A, Khan AA, Divya I \& Khan B (2001) Impact of fly ash on hatching, penetration and development of root-knot nematodes, Meloidogyne javanica. Nematologia Mediterranea 29: 215-218.

Thetwar LK (2007) Studies on the effects of fly ash and plant hormones and soil metabolic activities. Asian Journal of Chemistry 19: 3515-3518.

Upadhyay E (2004) Impact of particulate air pollutants on Brassica jiincea L. and Liniim usitatissimiim L., Ph.D. Thesis. Aligarh Muslim University. Aligarh.

Upadhyay E \& Khan AA (2002) Physico-chemical properties of fly ash and its impact on mustard. Environmental Biology \& Conservation 7: 85-88.

Wong MH \& Wong WC (1986) Effects of fly ash on soil microbial activity. Environmental Pollution Series A, Ecological and Biological 40: 127-144. 